\title{
Events and Their Inner Life: an Essay in Actual Eschatology
}

quel giorno più non vi leggemmo avante.

$(\operatorname{Inf} . \mathrm{V} .138)^{1}$

1. Preliminary considerations: patterns of eschatological awareness in Dante. 2. Axes of concern: the triumph of the innermost over the aftermost (the cases of Francesca da Rimini, Pier della Vigna and Guido da Montefeltro). 3. Conclusion: eschatology, immanence and the power to terrify.

Inasmuch as eschatology is ever ordinary, Dante's, in the Commedia, is an ordinary eschatology. ${ }^{2}$ Like most eschatology, it is expectational in

1 that day we read no farther in it.

${ }^{2}$ In general on Christian and Christian-medieval eschatology, R. Bultmann, History and Eschatology (Edinburgh: Edinburgh University Press, 1957); J. Moltmann, Theology of Hope: On the Ground and the Implications of a Christian Eschatology (London: SCM Press, 1968; also New York: Harper and Row, 1967); J. A. T. Robinson, In the End God (London and Glasgow: Fontana, 1968); J. Ratzinger, Eschatology (Washington DC: Catholic University of America Press, 1988; originally Eschatologie. Tod und ewiges Leben (Regensburg: Verlag, 1977)); W. Verbeke et al. (eds), The Use and Abuse of Eschatology in the Middle Ages (Leuven: Leuven University Press, 1988); Z. Hayes, Vision of a Future: A Study of Christian Eschatology (Wilmington DL: Michael Glazier, 1989); C. W. Bynum and P. Freedman (eds), Last Things: Death and Apocalypse in the Middle Ages (Philadelphia: University of Pennsylvania Press, 2000).

On Dante and eschatology, G. Barberi Squarotti, 'Artificio ed escatologia della Vita Nuova', in L'artificio dell'eternità. Studi danteschi (Verona: Fiorini, 1972), pp. 35-106; idem, 'Retorica ed escatologia', in Psicoanalisi e strutturalismo di fronte a Dante. Dalla letteratura profetica medievale agli odierni strumenti critici (Florence: Olschki, 1972), vol. 2 (Lettura della Commedia), pp. 441-65; R. Palgen, Mittelalterliche Eschatologie in Dantes 'Komödie'. Motive und motivketten aus der mittelalterlichen Sagen literatur. Die Timaiosmotive in der Göttlichen Komödie (Graz: Hugo-Schuchardtsche Malwinenstiftung, 1975); A. K. Cassell, Dante’d Fearful Art of Justice (Toronto: Toronto University Press, 1984); C. T. Davis, 'Poverty and Eschatology in the Commedia', in Dante's Italy (Philadelphia: University of Pennsylvania Press, 1984), pp. 42-70; M. P. Ciccarese, 'Le "Visiones" dell'aldilà nel cristianesimo occidentale. Genere letterario e tematiche predantesche', in La fine dei tempi. Storia ed escatologia, ed. M. Naldini (Florence: Nardini, 1994), pp. 101-15 (also, eadem (ed.), Visioni dell'aldilà in occidente: fonti, modelli, testi (Florence: Nardini, 1987) and 'L'anticipazione della 
character, anticipatory in respect of the moment in which, summoned before Christ in judgement, the individual will at last be confirmed in the truth of what he has been, of what he is, and of what now he always will be. And this, as a way of seeing and understanding it, chimes with the typological idea similarly decisive for an overall interpretation of the poem, with the notion that events severally disposed on the plane of the horizontal may by dint of their shared significance be said to inhabit the same space, to relate one with another by way of a complex process of preand post-shadowing. ${ }^{3}$ Eschatology and typology are in this sense all of a piece, each alike turning on a sense of the continuity of human experience in time and eternity, on a resolution of the what is under the aspect of the former in terms of the what will be under the aspect of the latter. ${ }^{4}$ But to

fine: l'immaginario dell'aldilà nei primi secoli cristiani', in R. Uglione (ed.) 'Millennium': l'attesa della fine nei primi secoli cristiani. Atti delle III Giornate Patristiche Torinesi, Torini 2324 ottobre 2000 (Turin: CELID, 2002), pp. 183-208); M. A. Palacios, Dante e l'islam. I. L'escatologia islamica nella 'Divina Commedia'. II. Storia e critica di una polemica, trans. R. R. Testa and Y. Tawfik, with an introduction by C. Ossola (Parma: Nuova Pratiche Editrice, 1994 and 1997; based on 2nd edn, 1943); M. Gragnolati, Experiencing the Afterlife. Soul and Body in Dante and Medieval Culture (Notre Dame, Ind.: University of Notre Dame Press, 2005); F. Livi, 'La Divina Commedia e l'escatologia cristiana', in Dante e la teologia (Rome: Casa Editrice Leonardo da Vinci, 2008), pp. 29-69.

${ }^{3}$ E. Auerbach, 'Figurative Texts Illustrating Certain Passages of Dante's Commedia', Speculum 21 (1946), 474-89 (also in Studisu Dante, ed. Dante Della Terza, 8th edn (Milan: Feltrinelli, 1991) pp. 239-63, with 'Figura' at pp. 176-226); idem, Typologische Motive in der mittelalterlichen Literatur; Schriftere und Vorträge desPetrarca-Instituts, Koln 2 (Krefeld: Scherpe, 1953); J. Chydenius, The Typological Problem in Dante: A Study in the History of Medieval Ideas (Helsinki: Societas scientiarum fennica, 1958); idem, The Theory of Medieval Symbolism (Helsinki: Societas scientiarum fennica, 1960); A. C. Charity, Events and Their Afterlife: The Dialectics of Christian Typology in the Bible and Dante (Cambridge: Cambridge University Press, 1966); G. Padoan, 'La “mirabile visione” di Dante e l'epistola a Cangrande', in Il pio Enea, l'empio Ulisse. Tradizione classica e intendimento medievale in Dante (Ravenna: Longo, 1977), pp. 30-63. Also, P. Armour, 'The Theme of Exodus in the First Two Cantos of the Purgatorio', in Dante Soundings. Eight Literary and Historical Essays, ed. D. Nolan (Dublin: Irish Academic Press, 1981), pp. 59-99. More generally on the typological issue, C. Spicq, Esquisse J'une bistoire de l'éxègese latine au moyen âge (Paris: Vrin, 1944); J. Daniélou, Sacramentum futuri. Etudes sur les origines de la typologie biblique (Paris: Beauchesne, 1950); idem, 'The Conception of History in the Christian Tradition', Journal of Religion 30 (1950), 3, 171-79; idem, Gospel Message and Hellenistic Culture (London: Darton, Longman and Todd, 1973; originally 1961); B. Smalley, The Study of the Bible in the Middle Ages, 2nd edn (Oxford: Blackwell, 1952); G. W. H. Lampe and K. J. Woollcombe, Essays on Typology (London: SCM Press, 1957); H. de Lubac, Exégèse médiévale. Les Quatre sens de l'écriture (Paris: Aubier, 1959-1964); idem, 'A propos de l'allégorie chrétienne', Recherches de science religieuse 47 (1959), 5-43 (also 'Typologie et allégorisme' in vol. 34 (1947), 180-226); J. N. D. Kelly, 'The Bible and the Latin Fathers', in The Churct's Use of the Bible, Past and Present, ed. D. E. Nineham (London: SPCK, 1963), pp. 41-56.

${ }^{4}$ On concepts of time and eternity in general and in Dante, P. Duhem, Le Système $\partial u$ monde. Histoire des doctrines cosmologiques de Platon à Copernic (Paris: Hermann, 1913-17 and 
live for any length of time with the Commedia is sooner rather than later to sense something of its restiveness with this kind of expectationalism, with its all being a matter, as far as the Ë $\sigma \alpha \alpha \tau o \zeta$ is concerned, of postponed intelligence. More exactly, it is to become aware of Dante's sense of the power of the historical instant to signify from out of the depths, the horizontal thus giving way to the vertical as a means of stating the eschatological issue. Now this needs careful statement, for to speak of the verticality of eschatological concern in the Commedia, of its sense of the $\ddot{E} \sigma \chi \alpha \tau o \zeta$ as dwelling in the depths of the historical instant, is by no means to sit lightly to what we have described as the expectational aspect of the argument, to the status of the $\ddot{\varepsilon} \sigma \chi \alpha \tau o \zeta$ as coming next or as following on; for everywhere built into the consciousness both of Dante himself and of his clientèle in the poem is a sense of the truth of their existence as but a truth in waiting, as subsisting in anticipation of its definitive statement. In

reprints, with a selection in Medieval Cosmology. Theories of Infinity, Place, Time, Void, and the Plurality of the Worlds, ed. and trans. R. Ariew (Chicago: University of Chicago Press, 1985)); W. Kneale, 'Time and Eternity in Theology', Proceedings of the Aristotelian Society 61 (1960-61), 87-108; W. von Leyden, 'Time, Number and Eternity in Plato and Aristotle, Philosophical Quarterly 14 (1964), 35-52; M. Kneale, 'Eternity and Sempiternity', Proceedings of the Aristotelian Society 69 (1968-69), 223-38; E. Stump and N. Kretzmann, 'Eternity', Journal of Pbilosophy 78 (1981), 429-58; R. C. Dales, 'Time and Eternity in the Thirteenth Century', Journal of the History of Ideas 49 (1988), 27-45; A. G. Padgett (with reference to Boethius and Aquinas), 'God and Time. Towards a New Doctrine of Divine Timeless Eternity', Religious Studies 25 (1989), 209-15; B. Leftow, 'Eternity and Simultaneity', Faith and Pbilosophy 8 (1991), 148-79; K. A. Rogers, 'Eternity has no Duration', Religious Studies 30 (1994), 1, 1-16; R. Sorabji, Time, Creation and the Continuum. Theories in Antiquity and the Early Middle Ages (Chicago: Chicago University Press, 2006, originally 1983). In relation to Dante, F. Masciandaro, La problematica del tempo nella "Commedia" (Ravenna: Longo, 1976); M. M. Chiarenza, 'Time and Eternity in the Myths of Paradiso XVII', in Dante, Petrarch, Boccaccio. Studies in the Italian Trecento in Honor of C.S. Singleton, ed. A. S. Bernardo and A. L. Pellegrini (Binghampton, NY: Centre for Medieval and Early Renaissance Studies, 1983), pp. 133-50; G. Giacalone, 'Tempo ed eternità nella Divina Commedia', in Dante Alighieri. La Divina Commedia (Roma: Signorelli, 1988), vol. 3, pp. 66-82 (subsequently in Atti Jella Dante Alighieri a Treviso 1984-1989 (Treviso: Matteo, 1989), pp. 170-81 and Da Malebolge alla Senna. Studi letterari in onore di Giorgio Santangelo (Palermo: Palumbo, 1993), pp. 259-78); I. Sciuto, 'Eternità e tempo in Dante', in Tempus, aevum, aeternitas. La concettualizzazione del tempo nel pensiero tardomedievale. Atti del Colloquio Internazionale, Trieste, 4-6 marzo 1999, ed. G. Alliney and L. Cova (Florence: Olschki, 2000), pp. 1-20; R. Bodei, Tempo ed eternità in Dante e in Petrarca, in Letture classensi 32-34, ed. N. Ancarani (Ravenna: Longo, 2005), pp. 67-76. More generally, P. Salm, Pinpoint of Eternity. European Literature in Search of the All-encompassing Moment, (Lanham: University Press of America, 1986). For Dante on eternity as duration, the 'e io etterno duro' of Inf. III.8, while on eternity as all-at-onceness (tota simul), Par. XVII.13-18 (the 'il punto / a cui tutti li tempi son presenti' of lines 17-18) and XXIX.10-12 ('Poi cominciò: "Io dico, e non dimando, / quel che tu vuoli udir, perch' io l'ho visto / là 've s'appunta ogne ubie ogne quando"'), where extension is present to the transfigured mind as a matter pre-eminently of intension, of the resolution of the quantitative in the qualitative as an inkling of the spirit. 
this sense, the $\ddot{\varepsilon} \sigma \chi \alpha \tau o \zeta$ is indeed the last thing horizontally, the terminus ad quem on the plane of temporality. But for all that, there can for Dante be no resolution of this matter in terms purely and simply of successionality, for his is a sense of ultimacy as a matter of intimacy, of what Kierkegaard used to call the 'infinite contentfulness' of the moment, ${ }^{5}$ at which point eschatology as often enough an afterthought in the mind of the theologian, an item under any other business, moves up the agenda.

2. What amounts, then, to a privileging of the vertical over the horizontal as a parameter of eschatological awareness, of the height and depth of that awareness over its before and after, is throughout discernible in the Commedia, Dante's at every stage being a preoccupation with the kind of awareness whereby self stands in the truth of self as confirmed from deep within it, from out of the innermost recesses of personality. Turning, then, to the case of Francesca in Inferno V, we have first its symptomatology, its registration $(a)$ of the surface sensation of being as adrift in respect of its own inner reasons, and (b) of the process of self-

${ }^{5}$ Søren Kierkegaard, The Concept of Anxiety, ed. and trans. R. Thomte in collaboration with A. B. Anderson (Princeton: Princeton University Press, 1980), p. 86: 'For representation, [the eternal] is a going forth that nevertheless does not get off the spot, because the eternal is for representation the infinitely contentful present.' Among the moderns, Paul Tillich, The Religious Situation, trans. R. Niebuhr (New York: Meridian Books, 1956), p. 35: 'it would not be worthwhile to speak at all of the fact that all sorts of things, ideas or feelings or deeds or works, move out of the past into the future across the mysterious boundary line of the present if all this were nothing but a moving, a flowing, a becoming and decaying without ultimate meaning or final importance. All of this is really important if it has unconditioned meaning, an unconditioned depth, an unconditioned reality. That it possesses this unconditioned meaning cannot be made a matter of proof or disproof but only of faith in the unconditioned meaning of life.' Karl Jaspers, Philosophy, trans. E. B. Ashton (Chicago: Chicago University Press, 1970; originally 1932), vol. 2, p. 17: 'Confronting necessity, the existence of an object at all times, we have, instead of endless time, the fulfilled time of the moment. As present eternity, this fulfilled time confronts Kant's time at large ... The latter is objective, measurable, and can be experienced as reality; the former is the depth of original, free Existenz. The latter is validly extant for everyone; the former turns a time that is tied to choice and decision into a phenomenon, as current time. Existenz has its time, not time pure and simple. Objective time exists for consciousness at large; existential time exists for the historical consciousness of Existenz alone' (emphases those of the translator). Among the depth-psychologists and psychoanalysts, Rollo May in Man's Search For Himself (New York: Norton, 1953, p. 269) speaks of eternity, not as a 'given quantity of time', but as its 'qualitative significance'. It is the form of man's relationship to life, 'not a succession of “tomorrows"'. Also, idem, The Discovery of Being (New York: Norton, 1983), p. 137: 'the Eigenwelt, the own world of self-relatedness, self-awareness, and insight into the meaning of an event for one's self, has practically nothing to do with Aristotle's clock time. The essence of self-awareness and insight are that they are "there" - instantaneous, immediate - and the moment of awareness has its significance for all time.' 
exoneration whereby the soul in its contritionlessness seeks to sidestep the pain of moral and ontological disintegration; on the one hand, then, there is the 'bufera infernal' passage beginning at line 28, an essay, precisely, in freefloatingness, in the agony of self-separation:

Io venni in loco d'ogne luce muto, che mugghia come fa mar per tempesta, se da contrari venti è combattuto.

La bufera infernal, che mai non resta, mena li spirti con la sua rapina; voltando e percotendo li molesta.

Quando giungon davanti a la ruina, quivi le strida, il compianto, il lamento; bestemmian quivi la virtù divina.

Intesi ch'a così fatto tormento enno dannati i peccator carnali, che la ragion sommettono al talento.

E come li stornei ne portan l'ali nel freddo tempo, a schiera larga e piena, così quel fiato li spiriti mali

di qua, di là, di giù, di sù li mena; nulla speranza li conforta mai, non che di posa, ma di minor pena. ${ }^{6}$

while on the other, there is the 'Amor ... Amor ... Amor' sequence beginning at line 100 and constituting an essay this time in the substance and psychology of self-evasion, in shifting the burden of guilt in the interests of a modicum of self-consistency:

"Amor, ch'al cor gentil ratto s'apprende prese costui de la bella persona che mi fu tolta; e 'l modo ancor m'offende.

Amor, ch'a nullo amato amar perdona, mi prese del costui piacer sì forte, che, come vedi, ancor non mabbandona.

${ }^{6}$ I came into a place mute of all light, which bellows like the sea in tempest when it is assailed by warring winds. The hellish hurricane, never resting, sweeps along the spirits with its rapine; whirling and smiting, it torments them. When they arrive before the ruin, there the shrieks, the moans, the lamentations; there they curse the divine power. I learned that to such torment are condemned the carnal sinners, who subject reason to desire. And as their wings bear the starlings along in the cold season, in wide, dense flocks, so does that blast the sinful spirits; hither, thither, downward, upward, it drives them. No hope of less pain, not to say of rest, ever comforts them. 
Amor condusse noi ad una morte.

Caina attende chi a vita ci spense".

Queste parole da lor ci fuor porte. ${ }^{7}$

7 Love, which is quickly kindled in a noble heart, seized this one for the fair form that was taken from me - and the way of it afflicts me still. Love, which absolves no one from loving, seized me so strongly with delight in him, that, as you see, it does not leave me even now. Love brought us to one death. Caina awaits him who quenched our life. On contrition as the breaking down of hardheartedness and as the condition, therefore, of regeneration, [Aquinas], ST IIIa supp. 1.1 resp.: 'Respondeo dicendum quod, ut dicitur Eccli. 10:15, initium omnis peccati est superbia, per quam homo sensui suo inhaerens, a mandatis divinis recedit. Et ideo oportet quod illud quod destruit peccatum, hominem a proprio sensu discedere faciat. Ille autem qui in suo sensu perseverat, rigidus, et durus per similitudinem vocatur; sicut durum in materialibus dicitur quod non cedit tactui; unde et frangi dicitur aliquis quando a suo sensu divellitur. Sed inter fractionem, et comminutionem, sive contritionem in rebus materialibus, unde haec nomina ad spiritualia transferuntur, hoc interest, ut dicitur, quod frangi dicuntur aliqua quando in magnas partes dividuntur, sed comminui vel conteri, quando ad partes minimas reducitur hoc quod in se solidum erat. Et quia ad dimissionem peccati requiruntur quod affectum peccati homo totaliter dimittat, quem per quamdam continuitatem, et soliditatem in sensu suo habebat; ideo actus ille quo peccatum dimittitur, contritio dicitur per similitudinem.' Bernard, In festo omnium sanct. I.x (PL 183, 458A): 'Equum indomitum flagella domant; animam immitem contritio spiritus et assiduitas lacrymarum'; Aelred of Rievaulx, Serm. de oner. XX (PL 195, 441A): 'Scopa terens cordis contritio est, qua Babylon in anima nostra teritur et conteritur, et omnes spurcitiae ejus egeruntur', etc.

Augustine on the alienation of responsibility in circumstances of far-offness, De civ. Dei xiv.14: 'Sed est peior damnabilior superbia qua etiam in peccatis manifestis suffugium excusationis inquiritur, sicut illi primi homines, quorum et illa dixit: "Serpens seduxit me, et manducavi", et ille dixit: "Mulier, quam dedisti mecum, haec mihi dedit a ligno, et edi". Nusquam hic sonat petitio veniae, nusquam inploratio medicinae. Nam licet isti non, sicut Cain, quod commiserunt negent, adhuc tamen superbia in aliud quaerit referre quod perperam fecit, superbia mulieris in serpentem, superbia viri mulierem. Sed accusatio potius quam excusatio vera est ubi mandati divini est aperta transgressio'; $D e$ lib. arb. III.ii.5: 'Verumtamen maximam partem hominum ista quaestione torqueri non ob aliud crediderim, nisi quia non pie quaerunt, velocioresque sunt ad excusationem, quam ad confessionem peccatorum suorum'; En. in psalm. vii.19 (v. 18): 'Ista confessio ita Dominum laudat, ut nihil possint impiorum valere blasphemiae, qui volentes excusare facinora sua, nolunt suae culpae tribuere quod peccant, hoc est, nolunt suae culpae tribuere culpam suam. Itaque aut fortunam, aut fatum inveniunt quod accusent; aut diabolum, cui non consentire in potestate nostra esse voluit qui nos fecit; aut aliam naturam inducunt, quae non sit ex Deo, fluctuantes miseri et errantes, potius quam confitentes Deo, ut eis ignoscat', etc. Peter Lombard, Comm. in ps. XL, v. 4: 'Miserere ita: "Sana" per flagella "animam meam”, quoniam nullo modo excuso peccatum, sed accuso dicens: "Quia peccavi tibi", non accuso fortunam, non dico: Hoc mihi facit fatum; non dico: Adulterum me fecit Venus, et latronem Mars, et avarum Saturnus'; Bernard, Cant. cantic. xvi.11: '[Confessio] oportet autem esse et simplicem. Non intentionem (forte quia latet homines) excusare delectet, si sit rea ... Primum illud non confessio est, sed defensio; nec placat, sed provocat ... Jam a postremo primi hominis dehortetur, exemplum, nec culpam siquidem diffitentis, nec tamen consequentis veniam non dubium quin ob reatus mulieris admistionem (Gen. 3:2). Genus excusationis est, cum argueris tu, alium incusare 
But of the strategies of self-preservation in the context of catastrophe Dante will have nothing, his being straightaway a referral of the horizontal to the vertical as the dominant axis of awareness, of the strategic to the synderectic as a principle of self-interpretation. 'Tell me', then, he has the poet-pilgrim say, 'how was it with you in the moment of love's sweet sighs, in the moment of knowing and of being known by love in its power both to delight and to destroy?' ('Ma dimmi: al tempo d'i dolci sospiri, / a che e come concedette amore / che conosceste i dubbiosi disiri?'; lines 118-20), ${ }^{8}$ a question which, for all its apparent innocence, leaves no room for manoeuvre, nowhere else for Francesca to look other than into the recesses of her soul there to contemplate yet again the enormity of it all, the awesome moment of moral and ontological self-delivery:

E quella a me: "Nessun maggior dolore che ricordarsi del tempo felice ne la miseria; e ciò sa 'l tuo dottore.

Ma s'a conoscer la prima radice del nostro amor tu hai cotanto affetto, dirò come colui che piange e dice.

Noi leggiavamo un giorno per diletto di Lancialotto come amor lo strinse; soli eravamo e sanza alcun sospetto.

Per più fiate li occhi ci sospinse quella lettura, e scolorocci il viso; ma solo un punto fu quel che ci vinse.

Quando leggemmo il disïato riso esser basciato da cotanto amante, questi, che mai da me non fia diviso,

la bocca mi basciò tutto tremante. Galeotto fu 'l libro e chi lo scrisse: quel giorno più non vi leggemmo avante".

$\left(\right.$ Inf. V.121-38) ${ }^{9}$

... In animam etenim suam peccat qui se excusat, repellens proinde a se indulgentiae medicinam, et sic vitam sibi proprio ore intercludens'; idem, De grad. humil. xvii.45: 'Si autem et de illa, sicut Adam vel Eva, convincitur, aliena suasione excusare se nititur', etc.

${ }^{8}$ But tell me, in the time of the sweet sighs, by what and how did Love grant you to know the dubious desires?

9 And she to me, "There is no greater sorrow than to recall, in wretchedness, the happy time; and this your teacher knows. But if you have such great desire to know the first root of our love, I will tell as one who weeps and tells. One day, for pastime, we read of Lancelot, how love constrained him; we were alone, suspecting nothing. Several times that reading urged our eyes to meet and took the colour from our faces, but one moment alone it was that overcame us. When we read how the longed-for smile was kissed by so great a lover, this one, who never shall be parted from me, kissed my mouth all trembling. 
Straightaway, then, the $\ddot{E}^{\prime}$ x $\alpha \tau o$, hitherto subsisting on the far limit of human experience in its moment-by-moment unfolding, is brought forward into the centre of that experience, at which point its power to terrify is intensified beyond words. Nothing, clearly, is lost here by way of horizontality, the terrified subject living on in a state of fear and trembling, of living dread in respect of the last judgement and of the second death. But everything is gained by way of immediacy, of a sense on the part of the subject of her standing even now in the truth of her existence under the conditions of time and eternity, at which point verticality - meaning by this the knowledge of self urged upon self from out of the depths - once again takes over as the dominant axis of concern.

As a further example of the ascendancy of the vertical over the horizontal as a plane of eschatological awareness in the Commedia we may take the case of Pier della Vigna in Inferno XIII, where again it is a question of self as summoned into its own presence from out of the recesses of self. Here too Dante starts out with the symptomatology of the case, with (a) the kind of paranoia characteristic of being in its remotion and referable to dividedness at the point of fundamental willing, and (b) the kind of selfexoneration functioning in circumstances of contritionlessness as the sole means of self-intelligibility in the individual, of his standing significantly in his own company. On the one hand, then, as an essay in the pathology of captivity and enslavement, in being under the aspect of intimidation, we have the 'Non fronda verde' passage beginning at line 1 :

Non era ancor di là Nesso arrivato, quando noi ci mettemmo per un bosco che da neun sentiero era segnato.

Non fronda verde, ma di color fosco; non rami schietti, ma nodosi e 'nvolti; non pomi v'eran, ma stecchi con tòsco. ${ }^{10}$

A Gallehault was the book and he who wrote it; that day we read no farther in it."

${ }_{10}$ Nessus had not yet reached the other side when we moved forward through a wood which was not marked by any path. No green leaves, but of dusky hue; no smooth boughs, but gnarled and warped; no fruits were there, but thorns with poison. Thomas on despair as, under one at least of its aspects, the gravest of sins, ST IIa IIae.20.3 resp.: 'Et ideo illud quod primo et per se habet aversionem a Deo est gravissimum inter peccata mortalia. Virtutibus autem theologicis opponuntur infidelitas, desperatio et odium Dei. Inter quae odium et infidelitas, si desperationi comparentur, invenientur secundum se quidem, idest secundum rationem propriae speciei, graviora. Infidelitas enim provenit ex hoc quod homo ipsam Dei veritatem non credit; odium vero Dei provenit ex hoc quod voluntas hominis ipsi divinae bonitati contrariatur; desperatio autem ex hoc quod homo non sperat se bonitatem Dei participare. Ex quo patet quod infidelitas et odium Dei sunt contra Deum secundum quod in se est; desperatio autem secundum quod eius bonum participatur a nobis. Unde maius peccatum est, secundum se loquendo, non credere Dei 
and, as similarly attuned to the notion of antagonism as a principle of cosmic interpretation, to the soul's inability to see in the world anything other than ill will, the 'Perché mi schiante' passage beginning at line 31:

Allor porsi la mano un poco avante

e colsi un ramicel da un gran pruno; e 'l tronco suo gridò: "Perché mi schiante?".

Da che fatto fu poi di sangue bruno, ricominciò a dir: "Perché mi scerpi? non hai tu spirto di pietade alcuno?

Uomini fummo, e or siam fatti sterpi: ben dovrebb' esser la tua man più pia, se state fossimo anime di serpi". ${ }^{11}$

while on the other hand, and as an essay this time in the kind of deflection whereby self is saved from the otherwise intolerable sensation of its inconsistency, of its delivery of self despite self to its own annihilation, there is the 'nfiammati infiammar sì Augusto' passage beginning at line 64:

La meretrice che mai da l'ospizio

di Cesare non torse li occhi putti, morte comune e de le corti vizio,

infiammò contra me li animi tutti;

e li 'nfiammati infiammar sì Augusto,

che ' lieti onor tornaro in tristi lutti. ${ }^{12}$

veritatem, vel odire Deum, quam non sperare consequi gloriam ab ipso. Sed si comparetur desperatio ad alia duo peccata ex parte nostra, sic desperatio est periculosior, quia per spem revocamur a malis et introducimur in bona prosequenda; et ideo, sublata spe, irrefrenate homines labuntur in vitia, et a bonis laboribus retrahuntur. Unde super illud Proverb. XXIV, "si desperaveris lapsus in die angustiae, minuetur fortitudo tua" dicit Glossa, nihil est execrabilius desperatione, quam qui habet et in generalibus huius vitae laboribus, et, quod peius est, in fidei certamine constantiam perdit'. Et Isidorus dicit, "in libro de summo bono, perpetrare flagitium aliquod mors animae est, sed desperare est descendere in Infernum".' Rarely, however, do the old theologians approach either the substance or intensity of Dante's sense of despair as inauthentic drivenness, as obsessive recourse to the self-consciously inauthentic solution, though Augustine comes close to it when he speaks of desperation as perseverance in impiety: 'in peccatis suis desperata atque impia mentis obstinatione perserverantibus' (Exp. inc. ep. ad Rom.); or as the 'piling up' of transgressions: 'et ex ipsa desperatione delicta cumulantes' (En. in psalm. cxliv.24; v. 20), etc.

11 Then I stretched my hand a little forward and plucked a twig from a great thornbush, and its stub cried, "Why do you break me?" And when it had become dark with blood, it began to cry, "Why do you tear me? Have you no spirit of piety? We were men, and now are turned to stocks. Truly your hand ought to be more merciful had we been souls of serpents".

12 The harlot that never turned her whorish eyes from Caesar's household - the common death and vice of courts - inflamed all minds against me; and they, inflamed, did so inflame Augustus that my glad honours were changed to dismal woes. 
Here again, however, Dante intervenes to banish the mists of illusion and of self-deception in favour of an act of self-recognition, of the kind of clear-sightedness which, captive for the most part to mere strategy and to the bad faith thereof, rises up in the critical instant to confront the individual with the truth of what he actually is as an agent of radical undoing - a situation confirmed at the level of style by the tortured substance of sound and syntax:

L'animo mio, per disdegnoso gusto, credendo col morir fuggir disdegno, ingiusto fece me contra me giusto.

(Inf. XIII.70-71) $)^{13}$

Survival at this depth being out of the question, the soul straightaway surfaces to take up the routine psalmody of self-recommendation (the 'Per le nove radici d'esto legno / vi giuro che già mai non ruppi fede / al mio segnor, che fu d'onor sì degno' of lines 73-75), ${ }^{14}$ this being the way in hell of pseudo-sanity, of affirming self in the unaffirmability of self. But as Pier della Vigna knows full well (for this is what it means to be in hell) the routine is just that - a routine - the whole thing, therefore, functioning as but a further co-efficient of despair.

As a third and for the moment final instance of this sense in Dante of the $\ddot{\varepsilon} \sigma \chi \alpha \tau o \zeta$ as a matter less of the forthcoming than of the indwelling we may take the case of Guido da Montefeltro in Canto XXVII of the Inferno, where again it is a question of Dante's gradually constraining the speaker, and thus by extension the reader, to the truth of his existence as inwardly abiding and thus as forever rising up after the manner of the Leviathan to tax him in conscience. First, then, comes the familiar moment of exoneration, the moment designed to save the subject from the pain and perplexity of self-acknowledgement:

Io fui uom d'arme, e poi fui cordigliero, credendomi, sì cinto, fare ammenda; e certo il creder mio venìa intero, se non fosse il gran prete, a cui mal prenda!, che mi rimise ne le prime colpe; e come e quare, voglio che m'intenda.

${ }^{13}$ My mind, in scornful temper, thinking by dying to escape from scorn, made me unjust against my just self. S. Vazzana, 'Il “disdegnoso gusto” di Pier de le Vigne', LiAlighieri, n.s. 39, 11 (1998), 91-94.

${ }^{14}$ By the new roots of this tree I swear to you that I never broke faith with my lord, who was so worthy of honour. 
Mentre ch'io forma fui d'ossa e di polpe che la madre mi diè, l'opere mie non furon leonine, ma di volpe.

$\mathrm{Li}$ accorgimenti e le coperte vie io seppi tutte, e sì menai lor arte, chal fine de la terra il suono uscie.

Quando mi vidi giunto in quella parte di mia etade ove ciascun dovrebbe calar le vele e raccoglier le sarte,

ciò che pria mi piacëa, allor m"increbbe, e pentuto e confesso mi rendei; ahi miser lasso! e giovato sarebbe.

$(\text { Inf. XXVII.67-84) })^{15}$

But then, and again in a manner decisive for any exact understanding of what is going on in the Inferno, of Dante's sense of reprobation as a matter of recognition, comes the change of direction, the constraining of the horizontal to the vertical as the axis of ontological intelligence. Impressed, therefore, by the inadequacy of every strategy of the spirit to the business in hand and constrained to what comes next by a sort of grim inevitability, the soul once more settles on the moment of its delivery, on the moment in which, despite every inclination to the contrary (for the inauthentic choice in hell is inauthentic only in the degree to which it is irradiated by a sense of authentic possibility, by a commitment at some level of consciousness to the what might be of historical selfhood), it opted and opts still for its annihilation, for its ceasing to be in any recognizably human sense of the term:

Ma come Costantin chiese Silvestro d'entro Siratti a guerir de la lebbre, così mi chiese questi per maestro

a guerir de la sua superba febbre; domandommi consiglio, e io tacetti perché le sue parole parver ebbre.

${ }^{15}$ I was a man of arms and then a corded friar, trusting, so girt, to make amends; and certainly my hope would have come full, but for the high priest - may ill befall him! who set me back in my first sins; and how and wherefore I would have you hear from me. While I was the form of the flesh and bones my mother gave me, my deeds were not those of the lion, but of the fox. I knew all wiles and covert ways, and plied the art of them so well that to the ends of the earth their sound went forth. When I saw myself come to that part of my life when every man should lower the sails and coil up the ropes, that which before had pleased me grieved me then, and with repentance and confession I turned friar, and - woe is me! - it would have availed. 
E' poi ridisse: "Tuo cuor non sospetti;

finor t'assolvo, e tu m'insegna fare

sì come Penestrino in terra getti.

Lo ciel poss'io serrare e diserrare, come tu sai; però son due le chiavi che 'l mio antecessor non ebbe care".

Allor mi pinser li argomenti gravi là 've 'l tacer mi fu avviso 'l peggio, e dissi: "Padre, da che tu mi lavi

di quel peccato ov'io mo cader deggio, lunga promessa con l'attender corto ti farà triunfar ne l'alto seggio”.

(Inf. XXVII.94-111) $)^{16}$

True, with Francis and the pantomimics of the dark angel we are once again on the plane of the horizontal, of the what bappens next of being under the aspect of eventuality. ${ }^{17}$ But the what happens next of being under the aspect of eventuality is a function in the Commedia of the what already

${ }^{16}$ But as Constantine sought out Sylvester within Soracte to cure his leprosy, so this one sought me out as the doctor to cure the fever of his pride. He asked counsel of me, and I kept silent, for his words seemed drunken. Then he spoke again, "Let not your heart mistrust. I absolve you here and now, and do you teach me how I may cast Penestrino to the ground. I can lock and unlock heaven, as you know; for which the keys are two, which my predecessor did not hold dear". Thereon the weighty arguments pushed me to where silence seemed to me the worst, and I said, "Father, since you do wash me of that sin into which I must now fall, long promise with short keeping will make you triumph on the high seat".

${ }^{17}$ On the notion of ius diaboli, of the devil's right to the body in its sinfulness, Augustine, Contra sec. Iul. resp.imper. opus ii.24: 'Necessario quippe sequitur, quia per commixtionem corporum origo progenitis est, si per originem malum in hominibus, per malum ius diaboli in homines, diabolum esse auctorem hominum, a quo est origo nascentium; $D e$ nupt. et concup. II.xxvii.44, etc., and also in both Gregory the Great and Bede. See too, however, and in a manner possibly decisive for Dante, Anselm in the Cur Deus bomo at I.vii: 'Sed et illud quod dicere solemus, Deum scilicet, debuisse prius per justitiam contra diabolum agere, ut liberaret hominem, quam per fortitudinem; ut, cum diabolus eum, in quo nulla mortis erat causa, et qui Deus erat, occideret, juste potestatem, quam super peccatores habebat, amitteret; alioquin injustam violentiam fecisset illi, quoniam juste possidebat hominem, quem non ipse violenter attraxerat, sed idem homo se sponte ad illum contulerat, non video quam vim habeat', with this later in the same chapter: 'Et puto illos, qui diabolum aliquam opinantur habere in possidendo homine justitiam, ad hoc inde adduci, quia vident hominem diaboli vexationi subjacere juste, et Deum hoc juste permittere: et idcirco putant diabolum illam juste inferre'. Otherwise, Jude 9: 'Cum Michael Archangelus cum diabolo disputans altercaretur de Moysi corpore, non est ausus iudicium inferre blasphemiae: sed dixit: Imperet tibi dominus'. A. McGrath, Iustitia Dei. A History of the Christian Doctrine of Justification: The Beginnings to the Reformation (Cambridge: Cambridge University Press, 1986), pp. 58 ff. 
is of that being, the eventual, in respect of the existential, constituting but a marker, a place-holder, a means of accessibility in respect of its otherwise dark substance. Never, in other words, is the É $\sigma$ \% $\alpha \tau o \varsigma$ present to the individual as a matter merely of denouement or of foreclosure. On the contrary, it subsists as the 'infinitely contentful' character of the moment, as that whereby, in and through a turning back of self upon the instant as apt both to signify and to signify ultimately, he is once again summoned into his own presence in the unnegotiability of that presence.

3. One of the remarkable things about the Commedia, or, more exactly, about Dante's cast of characters in the Commedia, is their continuing preoccupation with the past, with the situation which, though now behind them, continues to fill them with misgiving; so, for example, as bearing on the city as the first of the three great medieval estates, and on this as a cause for melancholy, these lines (97-111) from Paradiso XV:

Fiorenza dentro da la cerchia antica, ond' ella toglie ancora e terza e nona, si stava in pace, sobria e pudica.

Non avea catenella, non corona, non gonne contigiate, non cintura che fosse a veder più che la persona.

Non faceva, nascendo, ancor paura la figlia al padre, che 'l tempo e la dote non fuggien quinci e quindi la misura.

Non avea case di famiglia vòte; non v'era giunto ancor Sardanapalo a mostrar ciò che 'n camera si puote.

Non era vinto ancora Montemalo dal vostro Uccellatoio, che, com' è vinto nel montar sù, così sarà nel calo. ${ }^{18}$

while as bearing on the empire as the second of them, these (lines 85-97) from Purgatorio XVI:

Esce di mano a lui che la vagheggia prima che sia, a guisa di fanciulla

${ }_{18}$ Florence, within her ancient circle from which she still takes the tierce and nones, abode in peace, sober and chaste. There was no necklace, no coronal, no embroidered gowns, no girdle that was more to be looked at than the person. Not yet did the daughter at her birth cause fear for the father, for the time and the dowry did not outrun due measure on this side and that. Houses empty of family there were none, nor had Sardanapalus arrived yet to show what could be done in the chamber. Not yet was Montemalo surpassed by your Uccellatoio, which, as it had been passed in the uprising, so shall it be in the fall. 
che piangendo e ridendo pargoleggia,

l'anima semplicetta che sa nulla, salvo che, mossa da lieto fattore, volontier torna a ciò che la trastulla.

Di picciol bene in pria sente sapore; quivi s'inganna, e dietro ad esso corre, se guida o fren non torce suo amore.

Onde convenne legge per fren porre; convenne rege aver, che discernesse de la vera cittade almen la torre.

Le leggi son, ma chi pon mano ad esse? ${ }^{19}$

and on the Church as the third of them, these (lines 40-57) from Paradiso XXVII:

Non fu la sposa di Cristo allevata del sangue mio, di Lin, di quel di Cleto, per essere ad acquisto d'oro usata;

ma per acquisto d'esto viver lieto e Sisto e Pïo e Calisto e Urbano sparser lo sangue dopo molto fleto.

Non fu nostra intenzion ch'a destra mano d'i nostri successor parte sedesse, parte da l'altra del popol cristiano;

né che le chiavi che mi fuor concesse, divenisser signaculo in vessillo che contra battezzati combattesse;

né ch'io fossi figura di sigillo a privilegi venduti e mendaci, ond' io sovente arrosso e disfavillo.

In vesta di pastor lupi rapaci si veggion di qua sù per tutti i paschi: o difesa di Dio, perché pur giaci? ${ }^{20}$

${ }^{19}$ From his hands, who fondly loves it before it exists, comes forth after the fashion of a child that sports, now weeping, now laughing, the little simple soul, which knows nothing, save that, proceeding from a glad maker, it turns eagerly to what delights it. First it tastes the savour of a trifling good; there it is beguiled and runs after it, if guide or curb bend not its love. Wherefore it was needful to impose law as a bridle, it was needful to have a ruler who could discern at least the tower of the true city. Laws there are, but who puts his hand to them?

20 The spouse of Christ was not nurtured on my blood and that of Linus and of Cletus, to be employed for gain of gold; but for gain of this happy life Sixtus and Pius and Calixtus and Urban shed their blood after much weeping. It was not our purpose that one part of the Christian people should sit on the right of our successors, and one part on the left, nor that the keys which were committed to me should become the ensign on 
At every point the pattern is the same, the soul in its election living out still the agony of the historical instant, the blasphemous substance of what was and still is under the conditions of time and space. How are we to account for this situation? By way (a) of an anthropology and ethic committed as of the essence to the intrinsic dignity of the human project in its power to moral and ontological self-implementation; (b) of a secure sense of history as the whereabouts of that self-implementation, and $(c)$ of total seriousness on both counts. And with this we are back to our main theme, for in the degree to which Dante takes seriously the greatness and the locatedness of the human project he is committed willy nilly to an immanent eschatology, to an eschatology which, though by no means indifferent to its expectational aspect, turns upon the historical instant and the 'contentfulness' thereof as the whereabouts of ultimate self-interpretation. Its expectational aspect, everywhere dominant as a paradigm of consciousness, is in this sense but the forward projection of something more dreadful, of an immanent absolute empowered from within to devastate the spirit.

a banner of warfare on the baptized; nor that I should be made a figure on a seal to sold and lying privileges, whereat I often blush and flash. Rapacious wolves, in shepherd's garb, are seen from here above in all the pastures. O defence of God, wherefore does thou still lie still? 